\title{
What Makes a Utopia Inconvenient? On the Advantages and Disadvantages of a Realist Orientation to Politics
}

\author{
BENJAMIN L. MCKEAN Ohio State University
}

\begin{abstract}
Tontemporary politics is often said to lack utopias. For prevailing understandings of the practical force of political theory, this looks like cause for celebration. As blueprints to apply to political practice, utopias invariably seem too strong or too weak. Through an immanent critique of political realism, I argue that utopian thought, and political theory generally, is better conceived as supplying an orientation to politics. Realists including Bernard Williams and Raymond Geuss explain how utopian programs like universal human rights poorly orient their adherents to politics, but the realists wrongly conclude that utopias and other ideal theories necessarily disorient us. As I show through an analysis of utopian claims made by Michel Foucault, Malcolm X, and John Rawls, utopias today can effectively disrupt entrenched forms of legitimation, foster new forms of political identity, and reveal new possibilities within existing institutions. Utopias are needed to understand the political choices we face today.
\end{abstract}

W hat is the political force of utopian thinking? 25 years after the end of the Soviet Union, many answers to this question still seem marked by the experience of the Cold War. When taking that experience as exemplary, political estimations of utopia tend to oscillate between two extremes. Many worry that utopian thinking can swamp politics when it provides a radical social blueprint and inspires adherents to implement it mechanically (Kateb 1972). On the other hand, utopian thinking that fails to resemble a radical blueprint is dismissed as toothless, either because it cannot be applied to practical politics or because it all too closely resembles politics as it already is (Shklar 1998). Consequently, utopia is understood to have either too much or too little political force and so new replacement utopias-especially "The Last Utopia" of human rights - are invariably found wanting (Moyn 2010).

Perhaps as a result, the past decade has seen the striking rise of a realism that scorns utopian blueprints alongside attempts to decouple Marxism from the end of the Soviet Union in order to recuperate "The Idea of Communism" (Dsouzinas and Zizek 2010). In this article, I argue that a profound misunderstanding of how political theory can relate to political practice lies behind this prolonged crisis of utopianism. Contemporary political realism offers an important critique of utopian thinking that shows why attempts to apply it appear too strong or weak; however, rather than dismissing or marginalizing utopianism, as the realists themselves do, I show how their critique can illuminate its genuine utility. When one abandons the expectation that the political force of utopias must manifest itself through

Benjamin L. McKean is Assistant Professor, Ohio State University (mckean.41@osu.edu).

For comments and feedback on earlier drafts, the author thanks five anonymous reviewers for APSR, Dana Howard, Sean Aas, Eric MacGilvray, Jan-Werner Müller, Michael Neblo, David Plunkett, Lars Rensmann, Shalini Satkunanandan, Inés Valdez, Ardevan Yaghoubi, Alexander de la Paz, and Dasha Polzik as well as audiences at the American Political Science Association annual meeting and the Political Theory and Practical Philosophy Workshops at University of Chicago. attempts at application and instead considers how they can orient political actors to existing institutions, one can see utopian thinking making effective interventions by disrupting entrenched forms of legitimation, fostering new forms of identity, and revealing new potentials within existing institutional forms. These are important political and theoretical possibilities and we have good reason to value their liberatory potential on realist grounds.

Utopias take many forms, but for purposes of this argument, I will use utopian thinking to refer to depictions of or reflections on highly desirable and hopedfor social and political circumstances that include no necessary reference to the means, costs, or feasibility of achieving them from our present condition. Utopian thinking does not need to imagine a perfect societyhistorically, it rarely does (Sargent 2010,104) - but can, for example, envision worlds in which some contemporary problems are simply absent without proposing a plan for bringing that about. The charge that utopian thinking fails to engage appropriately with the practice of actual politics is a very old complaint-it is aimed at Socrates throughout Plato's Republic - but works by Raymond Geuss and Bernard Williams published over the past decade have given it new life by suggesting that the need for realism is especially timely in light of the contemporary search for new replacement utopias. ${ }^{1}$ It is a measure of the influence of this critique that many old thinkers are now returning to prominence under the realist banner, their ideas freshly re-certified as practical and nonutopian (Ciccariello-Maher 2014; Mantena 2012). Political realists have unsurprisingly raised a variety of concerns about utopias, but the complaint that I consider here is that utopian thinking fails to orient us to our actual circumstances and problems. As I will use the term, an orientation to politics concerns how we get our bearings in our social world by identifying those features we habitually

\footnotetext{
${ }^{1}$ For overviews of this resurgence in realism, see Galston (2010) and Rossi and Sleat (2014). For a survey of its intellectual roots in the work of Karl Popper and Isaiah Berlin, among others, see Jacoby (2005).
} 
regard as the most salient parts of the landscape and which we are consequently disposed to weigh in our considered judgment about what to do. ${ }^{2}$ Geuss and Williams argue that utopian thinking is constitutively unable to orient people properly to politics because of its theoretical methodology, which determines what is desirable or valuable without any reference to the particular political choices faced by really existing actors. For example, theorizing a world in which human rights are universally respected doesn't seem to make it easier to cope with a world in which the content of human rights is the subject of deep disagreement and in which the selective enforcement of human rights is used to advance national interests. Against thinking that is fundamentally unworldly and encouraging of illusions, Geuss and Williams suggest that we should be attuned above all to how people actually are and how politics really works so that we can be better oriented and take more effective political action. To the extent that they accord utopian thinking any beneficial practical role, it is as a source of motivation for engaging in politics, but never guiding how to do so.

Geuss and Williams have importantly different views in many respects, including about politics, but their work is united in polemically suggesting that the most important distinction in contemporary political thought and practice is between realists and others. In the profusion of secondary literature responding to Geuss and Williams and carrying their work forward, surprisingly few have asked how should their realism be evaluated on its own terms - that is, not only as a theoretical view but also as a political intervention? I will argue that the resultant orientation to politics is unnecessarily limited. Importantly, my argument differs from defenses of utopian thinking which take impractical political thought as a worthwhile end in itself (e.g., Estlund 2011). Using human rights as a case study, I show how realist critiques have obscured the emancipatory potential of regarding them as a utopian project. Political projects advancing human rights are not necessarily utopian, but imagining a world in which "the dignity of each individual will enjoy secure international protection" through the realization of the Universal Declaration of Human Rights (UDHR) is surely what historian and human rights critic Samuel Moyn calls "a recognizably utopian program" (Moyn 2010, 1).

Against the assumption - shared by Geuss, Williams, and Moyn alike - that the adherents of such utopian visions understand them as blueprints to be applied in practice, I argue that envisioning an ideal society need not be a precursor to attempts to build it. Rather, as I show by analyzing the uses of human rights by Malcolm X and Michel Foucault, utopian thinking can orient us to existing political institutions in ways that both track the operations of power and attend to real

\footnotetext{
2 This concept of orientation has important roots in Immanuel Kant but the conception used here is sufficiently general so that it is applicable to and used by non-Kantians and anti-Kantians. For Kant's view, see Kant (1991). For the use of orientation specifically by antiKantians, see Hutchings (2011).
}

opportunities for resistance. Through a counterintuitive reading of John Rawls's account of orientation, I argue that even an impossible-to-realize ideal theory can help us understand important features of our present circumstances. In short, a realism that seeks to facilitate effective political action should recognize its own interdependence with utopian thinking. Realism usefully highlights the cost of every political choice, but often overlooks the costs associated with adopting realism itself; an insistence on seeing things as they are can easily curdle into an insistence that things are as they must be, especially because new political possibilities are both risky and difficult to perceive. It is here that utopias retain their political force. No longer understood simply as blueprints for action or principles to be applied mechanically, utopias can give us a novel perspective on our own politics valuable on realist grounds.

\section{THE POLITICS OF PRIORITIZING IDEAL THEORY}

The project of defending utopian thinking on realist grounds may seem quixotic in light of what many take to be their obvious opposition. For example, William Galston begins his explanation of political realism with what he calls "the least surprising point - namely, realism's resolutely antiutopian stance" (Galston 2010, 394; see also Jubb 2015, 920). However, others perceive a more complicated relation; Enzo Rossi and Matt Sleat contend that "conceptually, nothing precludes realists from resurrecting the 1968 slogan 'Be realistic. Demand the impossible"" (Rossi and Sleat 2014, 690), even if few have actually done so in practice. Consequently, it is important to be specific about the particular realist objection to utopian thinking that I want to consider. In contrast to the tradition of thinking about politics that sees theorizing as pursuing truths that are essentially separate from political action, a realist approach focuses on how theories are lived now, as they shape ways of seeing the existing political world by drawing our attention to particular features of it. That habitual attention naturally leads political agents to act in particular ways, as some actions appear appropriate to the perceived environment while others become almost unthinkable. As Geuss puts it, "My interest is in the practical coherence of a certain general framework for orienting political action in the contemporary world" (Geuss 2001a, vii; hereafter, "HIP"). One of the strengths of this view is that a framework for orientation can draw from many different resources, including not only political theory but also other practices, like human rights, that shape our expectations of politics. Thus, for realists, the key question of political theory is not "what would an ideal society look like?" Rather, they ask, "what kind of political thinking will orient people most coherently and effectively to intervene in politics?" For Geuss, the answer is clear:

...political philosophy must be realist. That means, roughly speaking, that it must start from and be concerned 
in the first instance not with how people ought ideally (or ought 'rationally') to act, what they ought to desire, or value, the kind of people they ought to be, etc., but, rather, with the way the social, economic, political, etc., institutions actually operate in some society at some given time, and what really does move human beings to act in given circumstances. (2008, 9; hereafter, "PRP")

Rather than putting ideals first, Geuss wants to put the facts first (bracketing for now the question of where exactly ideals go). Political actors that fail to do thiswhether they draw those ideals from political theory or the UDHR - will almost certainly not promote their intended ends since they will habitually overlook the most important features of their circumstances. In this section, I consider Geuss's account of utopian thinking in political theory as a source of disorientation before turning to the role of utopian thinking in the political project of human rights next.

Geuss offered a particularly vivid symbol of his critique with the holiday card that he reportedly sent in 2004 juxtaposing portraits of Immanuel Kant and John Rawls with images of George W. Bush and prisoner abuse at Abu Ghraib (Worsnip 2013). Understanding how and why Geuss connects these philosophers to actions that they would plainly deplore will clarify the nature and limits of his analysis of utopian thinking's relation to orientation. ${ }^{3}$ In order to motivate action after the horrors of Holocaust, Rawls constructs a "realistic utopia" in which justice is fully realized "someday, somewhere" (Rawls 2001b, 127). But Geuss dismisses this consoling vision. ${ }^{4}$ In 2003 , he asked rhetorically about Rawls, "Are reflections about the correct distribution of goods and service in a 'well-ordered society' the right kind of intellectual response to slavery, torture, and mass murder?" (Geuss 2005, 31) To think about a utopia free of unjustifiable inequality is to miss the most pressing political problems that have to be faced now and, to that extent, may even be complicit in their perpetuation. Who needs utopia when you can't even prevent a catastrophe?

It may seem obvious that theorizing an ideal future would not orient its adherents to pressing contemporary problems, but Geuss's point is not merely that the utopian ambitions of egalitarian liberals distract them from preventing disaster, in the mode of Judith Shklar's "liberalism of fear" (Shklar 1998). Rather, Geuss argues that their understanding of the relationship between political thinking and political action disposes them to disorientation because of the conception of normativity they employ. Geuss refers to these alternatives to realism as "ethics-first" thinking, writing, "[t]he view I am rejecting assumes that one can complete the work of ethics first, attaining an ideal theory of how we should act, and then in a second step, one can apply that ideal theory to the action of political agents" (PRP, 8 ). Geuss believes that these two features necessarily go together:

\footnotetext{
${ }^{3}$ See also the discussion of the effect of intentional juxtaposition in Geuss (2014, 231-6).

${ }^{4}$ For Rawls's defense of realistic utopia as a response to Auschwitz, see Rawls (2001b, 11-2 and 19-23).
}

(i) Normative Priority: employing normative values whose relevance and importance are determined without any reference to the particular problems the thinker encounters in politics.

(ii) Politics as Application: understanding political practice as the application of a theory developed independently of engagement with politics itself.

On this view, the only possible use of a utopian vision whose normative desirability purports to transcend its circumstances is to serve as a blueprint for realizing that vision. While I will argue later that these two steps are in fact separable, Geuss is right that some of the most prominent contemporary forms of political theorizing conjoin both features to troubling effect.

In particular, many practitioners of ideal theory do produce "realistic utopias" that they take as blueprints, conceiving of political practice as an attempt to approximate an ideal theory of just social institutions. For those who engage in ideal theory as blueprint, normative priority is given to the envisioned future and present actions are oriented around it; if a present political opportunity appears incompatible with the utopian future, then that is all one needs to know in order to reject it. As A. John Simmons writes, "We, as theorists of justice, simply should not care which policies are politically possible (etcetera) unless those policies are also on an acceptable path to a just institutional structure" (2010, 34). Yet despite being identified as the aim of political practice, the desirability of the ideal future is determined without any reference to the means or costs of achieving of it; Thomas Pogge articulates the methodology of many such political philosophers when he makes a sharp distinction between the project of constructing an ideal theory and the challenges of realizing that vision, writing, "I say little about transition problems: about how the ideal society can be reached from where we are now, and what demands justice imposes on the transition" (2007, page x). Tragic choices among constrained options have no obvious role to play in the view. Despite this, political action today can be guided directly by a utopian future because it is there that the normative values that one should promote today are worked out. For example, in his theory of global justice, Luis Cabrera writes, "My claim is that, with a defensible set of global institutions in mind-one which plausibly would secure the rights of all persons - we can extrapolate duties that would apply in the present global system, including ones to move institutions closer to the target" $(2010,67)$. If I want to figure out what to do within the present global system, I look first of all to an envisioned future and only then to existing institutions.

For ideal theory as blueprint, existing politics appears primarily as imposing obstacles to achieving an ideal rather than as a realm with its own dynamics to be respected. Existing political institutions are accordingly either overlooked entirely or understood as having an a priori relation to the values that the view promotes. Such theories thereby offer idealized pictures of institutions where their flaws appear as correctable deviations from a conceptual model; in 
contrast, a realist analysis begins by observing the operations of power and thus bases its interpretation of existing institutions on their actual functioning. A key example here is the state. Consider Kant's conception of rights and justice, which Geuss provocatively links with Abu Ghraib. In his political writings, Kant argues that the rational state makes justice possible by making rights stable and enforceable in the world. Kant further argues that, because having a state enforce one's rights is a practical precondition to being able to enjoy those rights, the state's action through the rule of law cannot be an infringement on my rights and freedom so long as it is enforced equally and in good faith. ${ }^{5}$

On this interpretation, Kant uses an a priori argument to establish the universal rationality of the state, an actually existing institution in the world. This has significant effects on any resultant orientation to politics, making the state appear as a fixed point rather than a historically contingent development. We seem to already know in advance a state's most important features without having to inspect it. Geuss is rightly concerned about the effects of this since it tends to obscure the actual workings of power and to misunderstand the choices in front of us. This also has the statusquo-preserving effect of making it easy to justify states' existence and (often dubious) actions. So, while it may be hyperbolic to link Kant with the abuses of Abu Ghraib, it is plausible for Geuss to argue that Kant's view orients him to politics in a way that presumptively legitimizes state violence and directs attention away from the costs of creating and maintaining order. Any utopian thinking that reduces politics to a venue for the unmediated application of a priori normative values risk doing the same.

Geuss's critique illuminates why utopian thinking today appears too strong and too weak when we consider implementing it. On one hand, utopian thinking is too ambitious in describing an ideal without any attention to the means to realize it; to attend in the first instance to the features of an ideal future disposes the visionary to acts ill-suited to his surroundings. On the other hand, utopian thinking is not ambitious enough because the ideals described too closely resemble the world as it already is (Geuss 2010a, 429). While the values and ideals they hold up are meant to have been developed without any necessary reference to our contingent circumstances, "[u]topian thinking assumes that we have too much cognitive ability to detach ourselves from the world we actually live in, to "jump over our own shadow' as Hegel put it" and, as a result, "[turns] out to have the same basic defects of the present, merely magnified" (Geuss 2015, 155). The visions of just societies produced by contemporary egalitarian liberals have the same methodological problems as Kant's conception of the state; attempting to develop ideal theories of just institutions without first understanding the way real institutions operate produces utopias that, at best, do nothing to address real defects and, at worst, mistake existing flaws for fixed points of the

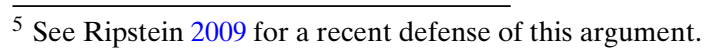

social world. Utopian thinking thus fails to provide an appropriate orientation to politics twice over-first, because it misidentifies the most salient features of a situation; second, because it leads the utopian thinker to misunderstand the character of his own agency and ideals.

\section{UTOPIAN THINKING IN POLITICAL PRACTICE}

For Geuss, ideal theory as blueprint represents the problem with utopian thinking in political theory, but it is human rights that exemplifies the pitfalls of utopian thinking in political practice. Though most human rights advocates do not have fully articulated philosophical methods and see themselves as responding directly to urgent crises, Geuss argues that they nevertheless advance ethics-first views. Advocates misunderstand how rights function in the world because, in order to make rights inviolable and urgent, they have given those rights a normative status that cannot be affected by empirical developments. ${ }^{6}$ On Geuss's view, the very idea of right requires that ethics "come first"; rights are meant to be respected in every circumstance, rendering the specifics of the situation of secondary importance. The practical failure to respect a human right does not undermine the normativity of the right; on the contrary, it only makes it more important to claim the right, often with perverse effects.

Geuss highlights three specific ways that the ethicsfirst orientation provided by a human rights framework ignores important features of politics and thereby facilitates ineffective action. First, the utopian vision of a world where everyone's human rights are protected is premised on denying the fact that political action always has a cost. How would conflicts among the rights enumerated there be resolved? Can such a world be achieved without violating human rights along the way? Do we have enough resources for everyone to enjoy the right to "periodic holidays with pay" asserted in Article 24 of UDHR? Geuss argues that there are no good answers to these questions because human rights are an "inconvenient fiction" that relies on "a fantastically optimistic view about God, the world, natural resources, and the avoidability of conflict" (HIP, 149). Geuss sees those who reject realism as wanting to have it all and asserts instead that "[p]olitics as we know it is a matter of differential choice: opting for A rather than B" and doing so at an advantageous time (PRP, 30, emphasis original). Lacking an orientation to the dichotomous nature of political choices, advocates are disposed to intervene in politics in ways dictated by their normative ideal rather than by evaluating the costs of competing options. In the face of a brutal dictator abroad, advocates are likely to say, "We have to do something!" because they assume that there must be something we can do when rights are violated. As a result of their utopian ideal, they are oriented to the

\footnotetext{
${ }^{6}$ Geuss assumes they all see human rights as natural rights, though that is false. The best argument against understanding human rights as natural rights is found in Beitz (2009).
} 
situation in a way that leads them away from considering the possibility that the costs of "doing something" may be higher than the costs of doing nothing.

Second, Geuss thinks that the ethics-first nature of an orientation to human rights ensures that advocates overlook power and have an incoherent relation to institutions and enforcement. Since the UDHR has no institution charged with its implementation, Geuss dismisses human rights as "no more than a moralizing conception about what would be desirable without any concrete specification of an enforcing agency" (HIP, 142). Instead, enforcement is left to states, which is foolish at best when we know that states overrule human rights all the time when it is convenient for their purposes (HIP, 148). Insisting that human rights be protected by states only gives them a further tool to legitimate their violence and, since states are the primary violators as well as the primary protectors of rights, Geuss thinks that this problem is insoluble. The disjuncture between how rights operate in our world, where powerful actors use them to advance their ends, and how they would operate in a utopia, where everyone's rights would be protected by impartial global mechanisms, is symptomatic of the way ethics-first orientations dispose people to overlook the centrality of power in politics.

Third, human rights doctrine orients its adherents to mistake their own character as political agents. In a recent interview, Geuss said, "To give priority to claiming rights gives us the completely wrong attitude toward ourselves, other political agencies and the state because it basically prioritizes us as passive clients of the nanny-state" $(2013,93)$. Human rights orient us to politics in a way that emphasizes the agency of states and the passivity of individuals without any tools for thinking about other forms of political organization or action since they lack a priori normative status. By taking individuals as the primary object of concern, the human rights framework relies on a "tacit (and utterly implausible form of) atomistic individualism" (2013, 93) that leads to ineffective political mobilization and facilitates state control. Demanding human rights entails understanding injustice as primarily a wrong done to individuals, which disposes people to respond as solitary victims.

In short, like egalitarian liberal ideal theories, the human rights utopia articulated by the UDHR and its proponents describes a desirable world without any reference to the means for its achievement while its hodgepodge of goals seem to aim simultaneously too high and too low. A right to holidays with pay may seem not merely unrealistic but irrelevant in a world where a billion people live on a dollar a day. At the same time, even global protection of the rights in the UDHR would fall short of a genuine utopia. Observing that the rise of the human rights movement in recent decades has accompanied the growth of economic inequality, Samuel Moyn notes in a Geussian spirit, "even were all the dreams of international human rights movements to be fulfilled, it is as much low ambitions as failures to realize them that made human rights companions of market fundamentalism" $(2015,15)$. In light of such problems, Geuss argues that, for anyone properly oriented to contemporary politics, the "last utopia" of human rights would not appear worth pursuing.

So, does Geuss believe that the point of political theory is simply to describe what politics is, counsel acceptance of it, and encourage quiescence? It can sound like this, as when Geuss calls his view "basically Hobbesian" (PRP, 22). But this is too simple. His realism chastens our normative ambitions by warning us away from utopian aspirations that take stability for granted or rest on an impossible agreement about values. As a consequence of this turn to the possible, his realism also chastens our methodological ambitions by exhorting us to remain close to the actual effects of power in our analysis, since such knowledge will be more useful for addressing the political choices we face. But Geuss imagines these Hobbesian requirements on theorizing to have liberatory potential: "Suppose now we decided to abandon the narrow limitations imposed on us by traditional ideas of what a 'philosophical ethics' could (and must) be. Then one could imagine ways of orienting ourselves in the world which went beyond the sorts of things envisaged and discussed in traditional forms of ethics" $(2014,192)$. Geuss sees realism not as an irksome constraint on the kinds of political theories we should offer, but as making possible a better kind of thinking and acting; one who adopts realism has simply been freed from illusory and impossible desires. We may not be able to achieve utopia, but perhaps, once we have left it behind, we will be able to see new possibilities that are good in their own ways.

\section{REALISM AS A GUIDE TO ACTION?}

Geuss makes a persuasive case that, in some important instances, utopian thinking orients its adherents to politics in a way that leads to incoherent, ineffective action. But Geuss's critique also raises difficult issues for his own alternative approach. Recall that he identifies ethics-first thinking as having two steps, first identifying a normative value and then applying it without attending to some essential features of politics. Because he sees the second step necessarily following from the first, Geuss suggests that the root of the problem with how ethics-first thinking guides political action is its conception of normative values. But does realism offer an alternative means of judging what to do?

Realists who accept Geuss's critique have essentially three paths to choose from: (1) realism could simply serve as a corrective for other views; (2) realism could guide action without providing normative evaluations; or (3) realism could provide its own conception of normative evaluation. If political realism is content to be merely a corrective, then it can let the other views supply the normative values and suggest either that the means to pursue those ends are unrealistic or that the values cannot be fully realized. On this reading, human rights doctrine is inconvenient by its own lights; realism does not offer a substantive or methodological alternative so much as it acts a permanent gadfly, assessing the coherence of other positions without offering any 
distinctive values of its own. A realism of this kind is an ethos or what Mark Philp calls "more like a code of honor ... [than] a set of metatheoretical claims" (2012, 637). A realism that refuses to be action-guiding could still be prescriptive in the sense that it counsels a clear-eyed confrontation with reality without having anything to say about what happens after that confrontation. This ethos typically narrates its bearer as a kind of tragic hero, one both freed by knowing the truth but also cursed to bear the opprobrium of those whose illusions he shatters. In these moods, Geuss also identifies his position with Theodor Adorno's; some circumstances require taking up a "merely negative" attitude without providing any reason to think shattered illusions can be replaced $(2005,9)$.

Yet Geuss often makes stronger claims for realism and suggests that it can facilitate better, more effective political action on its own. In places, he even suggests that realism should lead directly to some quite particular courses of action, such as "[fostering] further European integration" (2010a, 28). But how does one judge possible political actions without appealing to some values that they would promote? Sometimes Geuss suggests that once one adopts his perspective, its virtues will become evident (PRP, 17). That would be a doubly optimistic kind of realism, since it implies both an epistemic optimism that we have a reasonably reliable access to reality and a practical optimism that changing the way we talk about that reality will make things go better (Honig and Stears 2011). Such optimism runs counter to Geuss's own insistence on the persistence of disagreement. Even those who adopt a realist orientation to politics will surely offer competing interpretations of events, discern different possibilities for action, and seek to promote diverse ends. Geuss erases this pluralism when he conflates orientation and normative evaluation. While adopting political realism may suffice to rule out certain actions as self-defeating, it is rarely enough to defend the affirmative choice of a particular action.

If Geuss wants to offer a free-standing approach to political thinking (and it is not always clear that he does), then such a realism needs to be able to make explicit the value of the actions that it promotes. Consider the pressing political question of how the EU and its citizens should relate to a country abusing human rights. Geuss asserts that the EU should embrace China "in the interest of collaboration on the long-term goal of demilitarizing international politics" (2010a, 29). This is surely a worthy goal, but if political action should promote this aim, how does realism really differ from utopian thinking? Geuss acknowledges that "[i]t is a value judgment of a kind to think that a world in which the use of extreme military force is routine is, other things being equal, less good than one in which the use of force is uncommon" (2010a, 30). Geuss seeks to make his judgment more limited than the human rights advocate's by introducing a comparative element; he does not suggest, for example, that making military force uncommon is the sole end of politics and that all actions failing to promote this end are thereby impermissible. But the insufficiency of Geuss's conception of normative values is made clear by the phrase "other things being equal." If the EU were to abandon its alliance with the US to become closer to China, other things would not remain equal. In deciding to do so, the EU would surely need to make a judgment about how to weigh the other values at stake; concerns for the environment, prosperity, free speech, and stability may all pull in different directions. But because Geuss's criticism of utopian thinking assumes that prioritizing particular normative values leads directly to an orientation to politics as an application of those values, he minimizes his own reliance on normative values and does not address how to weigh them.

Rejecting an implausibly univocal realism thus puts Geuss in a bind: if he is to be entitled to the substantive political claims he wants to make (no to human rights, yes to an EU-China alliance), Geuss must reject his own methodological criticism of utopian thinking. Alternatively, he could rest content as a gadfly or, more dramatically, renounce the claim to facilitate better actions and say that a truly realist orientation reveals all our political actions to be equally meaningless. Geuss has oscillated among these positions, moving from an almost nihilistic despair to a measured appreciation of utopian thinking and back again. In the former vein, Geuss memorably stated that "[w]e are not, of course, now in a situation in which it is realistically possible for us to envisage any fundamental change in our world which we could ourselves bring about by our own efforts" $(2014,194)$. This politics of futility really does suggest that our actions do not much matter and, as a result, even the value of a clear-eyed confrontation with reality becomes doubtful.

However, in other moods, he has written that realism is not necessarily antiutopian (Geuss 2010b) and has gone so far as to say that "unless one thinks that we already live in the best of all possible worlds and that lack of flexibility in our relation to our own future is a good thing, giving up our utopian impulses completely would represent a serious loss" $(2015,158)$. Shadowed by the worry that utopian thinking will result in the reduction of politics to enacting blueprints, Geuss carefully refers to "utopian impulses," the content of which remains elusive, rather than utopian thinking, which provides more determinate content. ${ }^{7}$ Instead of seeing utopia as a potential aid to orientation, Geuss locates its practical political function elsewhere as when, in a discussion of Gustav Landauer, he notes that "utopian impulses are motivationally essential" $(2015,156)$. But this raises the question of what will adherents of utopia be motivated to do? Without articulating an alternative practical use for them, those who rely on utopias to motivate engagement in politics will likely default

\footnotetext{
${ }^{7}$ Jacoby similarly tries to separate a bad "blueprint tradition" of utopianism from a good "iconoclastic tradition," which "[refuses] to map out the future" $(2005,85)$. Part of the argument of this article is that it is the critics of utopian thinking, not the utopians themselves, who are conflating thinking with its application; once we recognize that the content of utopian thought can be employed as a means of orientation to existing politics rather than as a blueprint for the future, much of the attraction of the Bilderverbot valorized by Jacoby and Geuss drops away.
} 
to applying them as blueprints - precisely what Geuss wants to avoid. Consequently, we must look elsewhere for a realist account of the use of utopian thinking that can supplant the impulse to implement utopia.

\section{WILLIAMS AND POLITICAL NORMATIVITY}

If Geuss ends up opening the door for utopian thinking to play some practical role, how wide should realists open that door? Bernard Williams suggests that we need not wholly exclude from politics the normative values that make utopias desirable; rather, our orientations should simply restrict the range of normative values we attend to in politics, disposing us to attend to a similarly restricted set of political visions. Once again, human rights exemplify the problem with utopian thinking; against the "unfortunate" profusion of rights enumerated in the $\operatorname{UDHR}(2005,64)$, Williams argues that human rights should be sharply limited if they are to function appropriately in politics. However, this argument is as self-defeating as Geuss's. Williams pursues the third path open to Geuss and argues that utopian thinking leads to politics as application not because of the employment of normative value per se, but rather because utopia colonizes politics with nonpolitical values. However, I will argue that Williams's view also crucially relies on such nonpolitical values. This suggests that realists should abandon the view that politics as application is attributable to any methodological error in ambitious claim-making about normative desirability; there is no relation between the scope of a utopian vision and people's propensity to treat it as a blueprint for politics.

Geuss cites Bernard Williams's realism as influencing his own $(2005$; 2014), so the similarity of their approaches should be unsurprising. Williams too identifies with Hobbes and writes, "I identify the 'first' political question in Hobbesian terms as the securing of order, protection, safety, trust, and the conditions of cooperation. It is 'first' because solving it is the condition of solving, indeed posing, any others" $(2005,30)$. While Williams calls those outside the realist camp "political moralists" rather than "ethics-first" thinkers, their characteristic error once again concerns their conception of normativity and their number prominently includes Rawls, understood as the most important reproducer of Kant's erroneous "application" view (2005). Where Williams parts ways with Geuss is in offering a particular conception of desirable order that has a realist normativity conceived as internal to politics rather than imported from a morality established apart from it. Williams locates that normativity in people's pervasive concern with legitimacy. Williams introduces what he calls the Basic Legitimation Demand (BLD), which "can be equated with there being an 'acceptable' solution to the first political question" $(2005,4)$. The normative value of an order comes from this genuine acceptance by those subject to it and so we should accept great variation in views of what counts as a good reason to accept order. For example, according to Williams, inequality of status was quite compati- ble with legitimacy in medieval Europe, but conditions of modernity are such that people insist upon some form of equality as part of the BLD. Utopian thinking that sets higher aims for politics mistakes the values appropriate to a realm defined by power and disagreement.

Williams combines this acknowledgement of local variation in what counts as acceptable with the belief that there are nonetheless limits to what counts as politics at all. Williams considers a caste society with a minority group "no better off than enemies of the state" and which has no reason to see the state as anything other than sheer coercive force $(2005,5)$. Williams notes, "there is nothing to be said to this group to explain why they shouldn't revolt" (2005, 5, emphasis original) and so the BLD is clearly not met. Williams adds one further caveat: "the critical theory principle" calls for making sure that the structure of domination does not manipulate people into accepting the status quo $(2005,14)$. This principle makes the normativity of Williams's conception of order especially clear since it gives an observer a reason to think the BLD has not been met even when some of those subject to a state think otherwise. Williams's account thus helps us to see how a realist account could criticize orientations beyond offering an immanent critique of utopian aspirations. A useful orientation would facilitate practically coherent actions that contribute to order of the right kind-one freely accepted and legitimate according to the standards of those subject to it. An "inconvenient" orientation would fail to recognize that what counts as legitimate varies from place to place and time to time. For Williams, the refusal of universal applicability makes the normativity of his view internal to politics; where attempts to apply utopian thinking see politics as merely the venue for applying $a$ priori values, Williams's realism sees politics as the context from which values arise.

Despite this, Williams fails at differentiating his realist view of normativity from purportedly moralizing utopian views; human rights again help illustrate the problem. Williams writes, "the nearer political thought gets to action, as in the concrete affirmation of human rights, the more likely it is to be frivolous if it is utopian" $(2005,25)$ and so, against the UDHR, Williams defends a core of human rights against torture, the denial of religious expression, and other wrongs he regards as "obvious" $(2005,62)$. Such rights orient us to the boundary of politics since they mark when "the supposed solution [to the first political question], political power, [becomes] part of the problem" $(2005,63)$ and therefore can never be accepted as legitimate. But in addressing two situations of apparent human rights violations that concern communities with diverging conceptions of legitimacy - women's rights and humanitarian intervention - Williams's argument relies on values from outside politics. These are not marginal cases to consider and they frequently press practical dilemmas on us; an orientation that disposes us to overlook them is fatally incomplete. Williams's claims may be more limited than the political moralists he targets, but as with Geuss, the difference between the views concerns 
the scope of their extrapolitical requirements, not a difference in their kind. ${ }^{8}$

Consider the question of whether an egalitarian society should consider it a human rights violation when another country denies women the right to drive or vote. Williams writes, "the contemporary world is certainly within reach of the past, and the influences of the past include, now, theocratic conceptions of government and patriarchal ideas of the rights of women. Should we regard practices elsewhere that still express such conceptions as violations of fundamental human rights?" $(2005,70)$ and answers no. He writes, "[t]he charge that a practice violates fundamental human rights is ultimate, the most serious of political accusations. In their most basic form, violations of human rights are very obvious, and so is what is wrong with them: unmediated coercion, might rather than right" $(2005,72)$. Williams claims that the oppression of women is generally not a case of unmediated coercion because both men and women in theocratic and patriarchal societies are "jointly caught up in a set of beliefs which regulate their lives and are indeed unsound, but which are shared in ways that move the society further away from the paradigm of unjust coercion" $(2005,27)$. Williams worries that labeling such cases human rights violations will lead to disastrous interventions as advocates force norms of gender equity on a society that doesn't widely accept them. Since it would be straightforwardly illegitimate to install a new government to protect my preferred a priori standards of human rights when its subjects did not accept them, Williams believes political realism leads to a principle of noninterference in such cases. As he describes it, his view "tells [people] about certain judgments which they need not make" - that is, we can safely overlook such possibilities because there are neither philosophical nor political reasons to act on them $(2005,68){ }^{9}$

But there are a host of ways that someone who believes that women's rights are human rights could act because of that belief that avoid violating the BLD. Should egalitarians advocate for government policies that sanction such theocratic governments? Should they give money and support to indigenous feminist groups that are seeking to organize discontent and resistance? A realist orientation has no reason to direct attention away from these political possibilities. Williams has two options here: either his realism is indeterminate about cases where there are competing standards of legitimacy-which would undermine its claim to being an adequate source of orientation - or he must endorse noninterference on grounds he should regard as normatively "external" to politics. Williams

\footnotetext{
${ }^{8}$ Bavister-Gould (2013) also argues that Williams's view depends on universalizing ethical claims, but does so by emphasizing Williams's endorsement of the primacy of thick ethical ties. Erman and Möller (2015) argue that normative conceptions of legitimacy always rely on ethics-first reasoning even when the sources of normativity are exclusively political.

${ }^{9}$ Williams's view here is importantly related to his views about the nature of reasons, which largely lie outside the scope of this article See Williams (1981). For an account relating these views to Williams's political theory, see Flathman (2010).
}

opts for the latter and suggests that we ought not regard patriarchal oppression of women as one the "central core of evils" to which an international response is appropriate $(2005,74)$. This value judgment about the gravity of patriarchal oppression is not entailed by Williams's conception of politics, but rather is derived from normative and empirical considerations external to it-including a conservative view that counsels the preservation of existing conceptions of legitimacy until combating core evils requires some change in them.

In trying to carve out a set of "obvious" human rights from the broader utopian program of achieving a world that respects the UDHR, Williams converges with critics like Moyn, who writes, "preventing catastrophe through minimalist ethical norms and building utopia through maximalist political vision ... are absolutely different" and suggests that advocates "should restrict themselves to offering minimal constraints on responsible politics, not a new form of maximal politics of their own" (Moyn 2010, 226-7). But there is a cost to this effort to divorce human rights from utopianism: interpreting human rights as minimal constraints on politics implies that violations of those constraints are a form of domination located outside politics. Williams notes, "one lot of people terrorizing another lot of people is not a political situation" $(2005,63)$; as a result, even when the atrocities are perpetrated by governments on minority groups, he characterizes the resultant suffering as a kind of moral wrong. As Williams himself notes, this way of characterizing the situation opens the door to justifications of humanitarian intervention as "an enlightened imperialism" since it identifies the minority group as suffering victims rather than political agents $(2005,151)$. In sum, to rule out both noncoercive efforts to shift standards of legitimacy (as in his judgment that the oppression of women should not understood as a human rights violation) and coercion in the name of nonpolitical suffering (if he wishes to block imperialism), Williams needs some additional normative premise to support noninterference. But any such premise would not be internal to politics as he has construed it.

This problem is telling. In seeking to avoid the application of utopian visions to those that do not share them, these realists have consistently misunderstood the nature of their own position and its relation to utopian thinking - that is, they've mistaken the politics of their own intervention. At bottom, their differences with opponents are not philosophical disagreements about the nature of value; in defending their preferred policies, both Geuss and Williams make use of the kind of values they claim to reject. Rather, their crucial difference from their opponents is a practical disagreement about what we can do to address contemporary political problems. Their constrained sense of how ideals can be used in politics prevents them from recognizing the realist grounds for valuing utopian thinking and, as a result, their realism needlessly cuts off consideration of some genuine political possibilities, inadvertently supporting the status quo despite their professedly liberatory intent. To see this, the next section considers alternative uses of human rights 
that show how utopian claims can avoid politics as application.

\section{REALIST HUMAN RIGHTS?}

A political theory cannot implement itself and the way a theory is applied may have effects contrary to what the theory establishes as ideal, as when human rights are used to legitimize state violence. Geuss and Williams are right that many practitioners of utopian thinking fail to account for this. But they are wrong to assume that application or motivation are the only practical uses of utopias; exploring the ways that some utopian uses of human rights can orient their adherents to present political possibilities can resolve the impasse that realists face when they claim to distinguish themselves based on a distinctive approach to normativity. None of this undercuts the realist argument that human rights claims can legitimize dangerous exercises of state power at home and abroad, in part because they are seen as outside politics - but it is essential to note that this perception is carefully cultivated by some advocates rather than intrinsic to the concept. As Moyn notes, "if those who invented the contemporary human rights culture were utopians, they were Machiavellians too, devising a strategy that would allow their brand of transformation to differ from the world as it was but also from alternative political agendas - often by strategically denying that their aims were strategic at all” (2014, 25). Major human rights NGOs continue to strike this strategically apolitical pose despite the fact that it leads them to close alliances with human rights violators like the U.S. government. ${ }^{10}$ The realists are right to point out that utopian thinking that positions itself as above politics can serve oppressive ends. Yet, as Williams's approach to humanitarian intervention showed, realists actually exacerbate that danger by locating rights violations outside politics. A better response on realist grounds is to emphasize the political status of human rights claims so that they can be seen as contestable articulations of particular demands. Indeed, many advocates make use of human rights in precisely this way; instead of expressing a longing to transcend politics, human rights claims are often better understood as political claims against prevailing views of legitimacy and the orientations that support them.

To illustrate this possibility, I turn to two perhaps unlikely utopians: Michel Foucault and Malcolm X. Where the ideal theorist imagines a world in which everyone fully complies with the requirements of justice (Simmons 2010,3-5), these thinkers of what might be called oppositional utopias envision desirable but impracticable responses to existing injustices; in particular, by using human rights to imagine an impossible unity of the powerless that momentarily erases their internal political differences, they produce an orientation to politics that perceives important possibilities that would otherwise be overlooked. It is important not

\footnotetext{
${ }^{10}$ For a recent defense of this strategy by the executive director of Human Rights Watch, see Roth (2014)
}

to exaggerate the differences between ideal and oppositional utopias, however, since one can also engage in ideal theorizing that is appropriately oriented to real problems, as I argue in the next section. My point here is to show that avowedly utopian uses of human rights can contribute to an effective orientation to politics and so realists need not restrict them to a minimum core of claims or dismiss them entirely.

While it may surprise to turn to him here, Foucault argued explicitly that utopias can draw our attention to political possibilities in our own world, avowing his interest in the "actually realized utopias in which ... all the other real emplacements that can be found within the culture are, at the same time, represented, contested, and reversed" (1998, 178). The kinds of utopias that interest Foucault are those that exist in some form within our world, but which also point beyond and contradict it. Two primary forms of utopia recur throughout his work: first, "the profoundly and originally utopian experience of the body" (Foucault 2006, 233); second, revolts and uprisings - what he describes as "the possibility of this moment where life cannot be exchanged, where power becomes powerless, and where, in front of the gallows and the machine guns, men rise up" (Afary and Anderson 2005, 264). I focus on the latter-ways of imagining the surprising reversal of power relations through collective action. We can see what makes this utopian in Foucault's sense by turning briefly to his reporting on the Iranian revolution. Asking Iranians what they wanted in 1978, Foucault reports their replies: “'A utopia,' some told me without any pejorative implication. 'An ideal,' most of them said to me. At any rate, it is something very old and also very far into the future" (Afary and Anderson 2005, 206). For Foucault, revolt is utopian because uprisings have always happened but also point beyond themselves to a world in which the collective sense of possibility and unity of that moment impossibly continues beyond the revolt itself. Of course, such utopian visions can themselves become oppressive when taken up by the powerful, as the actual Iranian revolution vividly illustrated, but to imagine otherwise would be to endorse precisely a blueprint for ending politics entirely. Such "unmasking" of utopia or human rights as dangerously enmeshed in power relations could never serve to discredit them entirely to Foucault, though, since he believes that no discourse takes place outside of power relations (Patton 2004).

Nevertheless, this acknowledgement of the dangerous power of utopian thinking can help us to understand what Ben Golder aptly calls Foucault's "critical affirmation of rights discourse" (Golder 2011, 286). Foucault sees human rights as utopian precisely because they are embedded in our politics, but also point beyond it and can contest it; indeed, he even sees a human rights framework as helping us to orient us to the possibility of a global revolt. Consider his 1981 remarks at a press conference to promote an effort to defend Vietnamese boat people (available in Keenan 1987, 20-1). Speaking on behalf of "a certain shared difficulty in accepting what is happening," Foucault asserts the existence of "an international citizenry, which 
has its rights, which has its duties, and which promises to raise itself up against every abuse of power, no matter who the author or the victim." Foucault here uses rights talk to an eminently political end without making any claims to a prepolitical or a priori foundation and without legitimizing state action. On the contrary, the rights of this international citizenry come precisely from a clear-eyed assessment of real political institutions, as he avows when he says, "People's misfortune must never be a silent remainder of politics. It founds an absolute right to rise up and to address those who hold power." Unlike Williams's account of suffering as a moral wrong, Foucault avoids the trap of making those whose rights have been violated into victims in need of an enlightened imperial rescue. Instead, Foucault makes it clear that his own speech is political and interested, saying "After all, we are all governed and, to that extent, in solidarity."

Foucault's comments illustrate the potential for realist paths that Geuss and Williams miss. To speak of an international citizenry that takes direct action "against every abuse of power, no matter who the author or the victim" is a characteristic utopian hope insofar as it is both desirable and impracticable that everyone do what they ought to. But Foucault is not best understood as setting out a plan based on a priori principles or suggesting that we try to implement this utopian vision while ignoring possible political actions that are not on the path to its realization. Nor does Foucault's invocation of human rights constitute a repudiation of his earlier radical insights about power or a neoliberal turn that settles for the adequacy of traditional rights as a defense against domination, as some have argued (Paras 2006). Rather, Foucault asserts the rights of international citizenry as a response to the failure of institutions that ground their own legitimacy in a monopoly on rights protection. As Foucault explained in lectures given at the Collège de France in January 1976, his analysis typically aims "to understand power in its most regional forms and institutions, and especially at the points where this power transgresses the rules of right that organize and delineate it, oversteps those rules and is invested in institutions, is embodied in techniques and acquires the material means to intervene, sometimes in violent ways" (2003, 27-8). Geuss notably describes his own analysis of the way that rights talk reinforces some existing uses of power as Foucauldian $(2013,103)$, but unlike Geuss, Foucault maintains that the way institutions invariably overstep their own legitimizing rules also opens up possibilities for resistance. If relations of force can be naturalized and legitimized by the discourse of right, they can also be undone by turning rights talk against itself for liberatory ends; as he says in the context of gay rights, for example, "[r]ather than arguing that rights are fundamental and natural to the individual, we should try to imagine and create a new relational right that permits all possible types of relations to exist and not be prevented, blocked, or annulled by impoverished relational institutions" $(1997,158)$. Against Williams's and Moyn's suggestion that human rights be stripped of their utopian aspirations and Geuss's view that they be avoided entirely, Foucault suggests that imagining and claiming new rights can facilitate better political action. The impracticability of a global revolt to prevent human rights violations doesn't legitimate state intervention in its place; instead, this vision lends support to existing social movements assisting refugees while simultaneously drawing our attention to how a radically different world is required for people to genuinely enjoy their human rights. Such utopian thinking does not require us to detach ourselves from the world we actually live in, as Geuss feared, but instead takes seriously existing practices that can point to ideals beyond it.

While, in the abstract, to claim a right may be a way of asserting something inviolable, in practice, weaker parties claiming or asserting rights against more powerful parties are doing something quite different. Rights demands can also be assertions, seizures, and even performances of the very rights being demanded (Ingram 2013), as Malcolm X's use of human rights shows. Human rights were at the center of his political thinking following his departure from the Nation of Islam in 1964 and, prior to his assassination in 1965, he toured Africa and Europe for months to promote his plan to petition the United Nations to protest the U.S.'s violation of African-Americans' human rights (Harris 2008; Temkin 2012). He explained the value of human rights as an orientation to politics when he claimed that "[t]he difference between the thinking and the scope of the Negroes who are involved in the human-rights struggle and those who are involved in the civil-rights struggle is that those so-called Negroes involved in the human-rights struggle don't look upon themselves as Americans. They look upon themselves as a part of dark mankind" (1990, 51-2; see also 34-6). In distinguishing human rights from civil rights, Malcolm $\mathrm{X}$ recognizes that some rights claims can play the pacifying and status-quo-preserving role that the realists identify. But far from asserting an a priori universality, he used human rights claims specifically to polarize and assert difference, constructing a new political identity by refusing identification with the state and drawing attention to its repressive power.

Rather than assuming that everyone has the same relation to human rights, Malcolm X argues that AfricanAmericans have a particular political aim in claiming them: to undermine state power by appealing beyond it, to "dark mankind." He came to see human rights as the most effective political vehicle for an avowedly utopian Pan-Africanism, a desirable and impracticable form of unity among people of African descent throughout the world (Smith 1991). As with Foucault, the political efficacy of Malcolm X's vision does not depend on the possibility of realizing it. Regardless of whether "dark mankind" will ever exist as a unitary political force, the vision of it can nevertheless powerfully shape the self-understanding of political actors and facilitate new possibilities of action. In his view, civil rights advocates are ineffective because their identification with American citizenship has oriented them away from recognizing the way that white supremacy exercises power through institutions with which they 
identify; identification with "dark mankind" would better orient them to the operation of that power and to identify their own interests more readily. In his letter to the heads of state of the countries belonging to the Organization of African Unity, he likewise argues that a human rights framework would better orient them to the role of white supremacy in global politics and dispose them to an alliance with African-Americans: "You will never be fully respected until and unless we are also respected.... Our problem is your problem. It is not a Negro problem, nor an American problem. This is a world problem; a problem for humanity. It is not a problem of civil rights but a problem of human rights" $(1990,75)$. Where Geuss sees human rights as weakening social movements by orienting its adherents to individual victims, Malcolm X's act of claiming human rights is itself an assertion of collective political power and agency that makes it possible to track power and perceive political possibilities - in this case, for transnational solidarity - that might otherwise be overlooked.

The realists acknowledge that we do not know the limits of what is possible in politics. Geuss says that offering responsible answers to political questions means "thinking about them in a space organized around possible alternatives to the present existing state of affairs" (2005b, 39) and Williams affirms that "we should explore what more radical and ambitious forms of participatory or deliberative democracy are possible" (2005, 17). Yet exploring the space of possible alternatives requires utopian thinking that can help us to see new possibilities in the present, even if the worlds they describe are impracticable. Foucault's "international citizenry" may not literally rise against every abuse of power internationally, but his invocation of such a world illuminates opportunities for direct action; Malcolm X's use of human rights to orient African-Americans towards identifying with "dark mankind" rather than American citizenship similarly points political action down new paths for transnational solidarity. The end of the Cold War has only amplified the importance of nonstate actors in world politics and these oppositional utopias offer a model of how effective orientations to such a complex world might be imagined.

Realism stands against the belief that we can have it all and, to combat that kind of wishful thinking, foregrounds the idea that a responsible politics entails accepting some loss. Moyn applies this thought to human rights and suggests that "in the long view, the search for rights beyond [the state] may have been at a considerable price: the loss of the inclusive space of membership that the concrete state, and even empire, had long provided in some form or other" (Moyn 2010, 42). I do not wish to contest Moyn's historical judgment, but to suggest that this nostalgia for the nation-state provides a poor model for orienting us effectively to whatever liberatory political possibilities there may be now. It is true that the UDHR does not provide a blueprint for addressing the economic inequality that concerns Moyn and Geuss, but as I have argued, the primary practical use of utopian thinking is not its application. Assuming otherwise leads Moyn to dismiss the use of human rights by Malcolm $\mathrm{X}$ and other African-American radicals as "a minor feature of a larger anticolonialism" (Moyn 2010, 106) because their plans were not put into action, but that mistakes their value. Their uses of human rights model the possibility of utopian thinking orienting people to political interests that more minimal views overlook. If one aims to orient people to a shared interest in opposing inequality in the global economy today, it is important to ask what better accomplishes this: utopian visions of a world where everyone enjoys periodic holidays with pay or Moyn's return to a national framework, which disposes adherents to see their interests in competition with other countries? As this suggests, a realist politics is not exempt from its own insight that every political choice entails a loss; for a politics that begins with the way existing institutions operate, it will always seem dubious for the powerless to oppose the plans of those in power. If realists want political theory to do its part in intervening to stop catastrophe, then they would do well to consider all the tools available to them.

\section{AN EFFECTIVELY UTOPIAN ORIENTATION?}

Foucault and Malcolm X illustrate how we can appreciate utopian thinking as a source of orientation to the present rather than as a blueprint for the future and so avoid the pervasive dissatisfactions that have characterized evaluations of utopia's political efficacy since the Cold War. In closing, I want to consider an alternative way of practicing political theory in light of these oppositional utopians as well as the realist critique of applying utopian thinking. Where ideal theory as blueprint fixes the future and then proclaims that we should march towards a predetermined destination, a view of ideal theory as orientation suggests that a utopia isn't worth pursuing if it can't orient us to the here and now. I develop this view by considering John Rawls, whom the realists identify as their leading contemporary opponent. While realists correctly note that Rawls's view lacks an adequate conception of power, they overlook the fact that Rawls specifically asserted that "[n]either political philosophy nor justice as fairness ... is applied moral philosophy" (2001a, 14). Attending to this surprising strand in Rawls's work not only reverses a common interpretation of his thought (as suggested by the fact that Simmons and Pogge take themselves to be following Rawls), but also provides a useful framework for extending the force of utopian thinking in political theory today.

In a 1983 lecture, Rawls said, "Williams is right that there can be no ethical theory as he describes it, that is, a philosophical structure which together with some degree of empirical fact, yields a decision procedure for moral reasoning... Perhaps, though, while it cannot provide a decision procedure, it can provide something else" (Forrester 2012, 264). What can it provide? In Justice as Fairness: A Restatement, Rawls strikingly calls orientation one of the primary aims of political philosophy. He writes, "the members of any civilized society need a conception that enables them to 
understand themselves as members having a certain political status-in a democracy, that of equal citizenship - and how this status affects their relation to their social world. This need political philosophy may try to answer, and this role I call that of orientation" (2001a, 2-3). Like the realists, Rawls's account of orientation is contextual rather than a priori and he endorses the idea that facilitating action requires knowledge of one's social world and the way that legitimating ideas shape political statuses in that world. ${ }^{11}$ Rawls emphasizes orientation as a response to a particular practical obstacle to political action; in a modern social world characterized by complex systems of interdependence, it is impossible for most people to understand fully how their actions contribute to their society and in turn rely on the contributions of others. In order to be appropriately responsive to others in this context, individuals need to understand themselves as playing a particular role. But equal citizenship is only one orienting role. One of the tasks of utopian thinking today is to propose more such roles to guide political action that involves those who are not officially co-citizens, as Foucault and Malcolm X attempted with their respective invocations of "international citizenry" and "dark mankind."

Of course, even people in actually existing democracies do not enjoy genuinely equal citizenship. How then could Rawls's utopian invocation of genuinely equal citizenship orient us effectively to an unjust present? Geuss and Williams acknowledge that society is always a mixture of cooperation and conflict, but take it as a given that a responsible orientation must direct political actors to attend to the pervasiveness of conflict and thus the fragility of order. Rawls proposes an alternative orientation to these same facts. The most effective means of managing conflict may not be to insist on its centrality or inevitability. According to Rawls, we are much more likely to maintain a social order when we orient ourselves to other members of society as individuals with equal status with whom we share some interests (e.g., maintaining order) even as we conflict in other areas. His view is that we may avoid repeating our violent history if we habitually attend to the benefits from being in society and interpret society as a cooperative project with others as equal partners. This doesn't mean Rawls is so naïve as to think that all Americans currently enjoy truly equal political status (2001a, 13640). Neither does such a suggestion presuppose an end to conflict (Rawls 1996, xviii-xix and 54-8). Instead we might interpret Rawls along the lines suggested by Williams's distinction between politics and domination (Jubb 2015); attending to the way that political disagreements presuppose the renunciation of domination may make such disagreements more amenable to resolution.

By orienting ourselves to those institutions and practices where values are partially and imperfectly instantiated in the world, we are better able to act in ways that promote the fuller realization of those values. For

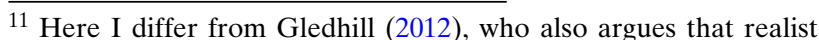
criticisms of Rawls misfire but does so by defending the practicality of acting as though we are already in a kingdom of ends.
}

Rawls as for the realists, a political theory fails when it tends to produce actions with effects that are contrary to the values that the theory promotes. In that sense, the normativity is immanent to the orientation rather than directing it from outside. If being oriented by Rawls's utopian vision does not dispose its adherents to actions that promote equality in our society, then it will have failed by its own lights. And Rawls's vision should be faulted on these terms. While the realists misunderstand the nature of their dispute with Rawls, they are right that he fails to develop a language to talk about power that would make it possible to orient one's actions to it (PRP, 90). Rawls's own ideal theory avoids offering an a priori interpretation of institutions as Kant does, but is nevertheless left profoundly onesided; it provides a way to see the value in existing institutions without a means to analyze their problems. But attending to power can change our fundamental interpretation of existing institutions. As Malcolm X suggested, deciding whether or not American institutions even partially instantiate the value of equality rather than using it as ideological cover for white supremacy requires judgments about both empirical and normative matters. Through the idea of ideal theory as orientation, Rawls illuminates what effective utopian thinking can be today, though his own theory falls regrettably short.

If the search for replacement utopias that began 25 years ago is ever to come to an end, it will not be because the right blueprints are finally discovered nor because people decide to put aside their utopian hopes entirely. To end this prolonged impasse in which utopia seems both necessary and impossible, we need to change what we are searching for. Geuss and Williams show us that political theory should not offer a plan, but an orientation; however, they unduly constrain the politics of their intervention by suggesting that utopia has no appropriate role to play as a source of orientation. I have argued that utopian thinking can and should aim at developing orientations that both facilitate a realistic power analysis of existing institutions and attend to the utopian paths made possible by those institutions' partial and deeply imperfect instantiations of values like equal, freedom, and human rights. If political thinking and political action are to be productively linked, both realism and utopia are essential today.

\section{REFERENCES}

Afary, Janet, and Anderson, Kevin B. 2005. Foucault and the Iranian Revolution: Gender and the Seductions of Islamism. Chicago: University of Chicago Press.

Bavister-Gould, Alex. 2013. "Bernard Williams: Political Realism and the Limits of Legitimacy." European Journal of Philosophy 21 (4): 593-610.

Beitz, Charles. 2009. The Idea of Human Rights. New York: Oxford University Press.

Cabrera, Luis. 2010. The Practice of Global Citizenship. New York: Cambridge University Press.

Ciccariello-Maher, George. 2014. "Decolonial Realism: Ethics, Politics and Dialectics in Fanon and Dussel." Contemporary Political Theory 13 (1): 2-22.

Dsouzinas, Costas, and Slavoj Zizek, eds. 2010. The Idea of Communism. Brooklyn, NY: Verso. 
Erman, Eva, and Niklas Möller. 2015. "Political Legitimacy in the Real Normative World: The Priority of Morality and the Autonomy of the Political." British Journal of Political Science 45 (1): 215-33.

Estlund, David. 2011. "What Good Is It? Unrealistic Political Theory and the Value of Intellectual Work." Analyze und Kritik 33 (2): 395-416.

Flathman, Richard. 2010. "In and Out of the Ethical: The Realist Liberalism of Bernard Williams." Contemporary Political Theory 9 (1): 77-98.

Forrester, Katrina. 2012. "Judith Shklar, Bernard Williams and Political Realism.” European Journal of Political Theory 11 (3): 247-72.

Foucault, Michel. 1997. Ethics: Subjectivity and Truth (Essential Works of Foucault, 1954-1984, Vol. 1), ed. Paul Rabinow. New York: The New Press.

Foucault, Michel. 1998. Aesthetics, Method, and Epistemology (Essential Works of Foucault, 1954-1984, Vol. 2), ed. James D. Faubion. New York: The New Press.

Foucault, Michel. 2003. "Society Must Be Defended," trans. David Macey. New York: Picador.

Foucault, Michel. 2006. "Utopian Body." In Sensorium: Embodied Experience, Technology, and Contemporary Art, ed. Caroline A. Jones, trans. Lucia Allais. Cambridge, MA: MIT Press, 229-34.

Galston, William. 2010. "Realism in Political Theory." European Journal of Political Theory 9 (4): 385-411.

Geuss, Raymond. 2001. History and Illusion in Politics. New York: Cambridge University Press.

Geuss, Raymond. 2005. Outside Ethics. Princeton, NJ: Princeton University Press.

Geuss, Raymond. 2008. Philosophy and Real Politics. Princeton, NJ: Princeton University Press.

Geuss, Raymond. 2010a. Politics and the Imagination. Princeton, NJ: Princeton University Press.

Geuss, Raymond. 2010b. "Realismus, Wunschdenken, Utopie." Deutsche Zeitschrift für Philosophie 58 (3): 419-29.

Geuss, Raymond. 2013. "Human Rights: A Very Bad Idea." Theoria: A Journal of Social and Political Theory 60 (2): 83-103.

Geuss, Raymond. 2014. A World Without Why. Princeton, NJ: Princeton University Press.

Geuss, Raymond. 2015. "The Metaphysical Need and the Utopian Impulse." In Actions, Reasons and Reason, eds. Ralf Stoecker and Marco Iorio (Berlin: De Gruyter, 2015), 14160.

Gledhill, James. 2012. "Rawls and Realism." Social Theory and Practice 38 (1): 55-82.

Golder, Ben. 2011. "Foucault's Critical (Yet Ambivalent) Affirmation: Three Figures of Rights." Social \& Legal Studies 20 (3): 283312.

Harris, Robert L. 2008. "Malcolm X: Human Rights and the United Nations." In Malcolm X: A Historical Reader, eds. James L. Conyers, Jr. and Andrew P. Smallwood. Durham, NC: Carolina Academic.

Honig, Bonnie, and Marc Stears. 2011. "The New Realism: From modus vivendi to Justice," Political Philosophy versus History? eds. Jonathan Floyd and Marc Stears. New York: Cambridge University Press, 177-205.

Hutchings, Kimberly. 2011. "What is Orientation in Thinking? On the Question of Time and Timeliness in Cosmopolitical Thought." Constellations 18 (2): 190-204.

Ingram, James. 2013. Radical Cosmopolitics. New York: Columbia University Press.

Jacoby, Russell. 2005. Picture Imperfect: Utopian Thought for an Anti-Utopian Age. New York: Columbia University Press.
Jubb, Robert. 2015. "Playing Kant at the Court of King Arthur." Political Studies 63 (4): 919-34.

Kant, Immanuel. 1991. "What is Orientation in Thinking?" In Kant: Political Writings, 2nd enlarged edition, ed. Hans Reiss. New York: Cambridge University Press, 237-49.

Kateb, George. 1972. Utopia and Its Enemies. New York: Schoken Books.

Keenan, Tom. 1987. "The 'Paradox' of Knowledge and Power: Reading Foucault on a Bias." Political Theory 15 (1): 5-37.

Mantena, Karuna. 2012. "Another Realism: The Politics of Gandhian Nonviolence." American Political Science Review 106 (2): 455-70.

Moyn, Samuel. 2010. The Last Utopia: Human Rights in History. Cambridge, MA: Harvard University Press.

Moyn, Samuel. 2014. "Human Rights in Heaven." In Human Rights: Moral or Political? ed. Adam Etinson. Forthcoming. Available at http://ssrn.com/abstract=2432448.

Moyn, Samuel. 2015. "Human Rights and the Age of Inequality." In Can Human Rights Bring Social Justice? eds. Doutje Lettinga and Lars van Troost. Amsterdam: Amnesty International Netherlands, 11-6.

Patton, Paul. 2004. "Power and Right in Nietzsche and Foucault." International Studies in Philosophy 36 (3): 43-61.

Paras, Eric. 2006. Foucault 2.0: Beyond Power and Knowledge. New York: Other Press.

Philp, Mark. 2012. "Realism without Illusions." Political Theory 40 (5): 629-49.

Pogge, Thomas. 2007. John Rawls: His Life and Theory of Justice, trans. Michelle Kosch. New York: Oxford University Press.

Rawls, John. 1996. Political Liberalism. New York: Columbia University Press.

Rawls, John. 2001a. Justice as Fairness: A Restatement, ed. Erin Kelly. Cambridge, MA: Harvard University Press.

Rawls, John. 2001b. The Law of Peoples; with "The Idea of Public Reason Revisited.” Cambridge, MA: Harvard University Press.

Ripstein, Arthur. 2009. Force and Freedom: Kant's Legal and Political Philosophy. Cambridge, MA: Harvard University Press.

Rossi, Enzo, and Matt Sleat. 2014. "Realism in Normative Political Theory." Philosophy Compass 9 (10): 689-701.

Roth, Kenneth. 2014. "The End of Human Rights?" New York Review of Books, October 23, 2014. 61 (16) http://www.nybooks.com/ articles/archives/2014/oct/23/end-human-rights/.

Sargent, Lyman Tower. 2010. Utopianism: A Very Short Introduction. New York: Oxford University Press.

Shklar, Judith 1998. Political Thought and Political Thinkers, ed. Stanley Hoffmann. Chicago: University of Chicago Press.

Simmons, A. John. 2010. "Ideal and Nonideal Theory." Philosophy and Public Affairs 38 (1): 5-36.

Smith, Curtis C. 1991. "Nkrumaism as Utopianism." Utopian Studies 1 (3): $31-6$

Temkin, Moshik. 2012. "From Black Revolution to 'Radical Humanism': Malcolm X between Biography and International History." Humanity 3 (2): 267-88.

Williams, Bernard. 2005. In the Beginning Was the Deed: Realism and Moralism in Political Argument, ed. Geoffrey Hawthorn. Princeton, NJ: Princeton University Press.

Williams, Bernard. 1981. "Internal and External Reasons." In Moral Luck. New York: Cambridge University Press, 101-13.

Worsnip, Alex. 2013. "What's the Point of Political Philosophy?" Prospect Blog http://www.prospectmagazine.co.uk/blog/ philosophy/realism-idealism-political-philosophy-david-millerjustice-for-earthlings/.

X, Malcolm. 1990. Malcolm X Speaks, ed. George Breitman. New York: Grove. 